\title{
Exploring E-Learning Readiness as Mediating between Trust, Hedonic Motivation, Students' Expectation, and Intention to Use Technology in Taibah University
}

\author{
Firas Tayseer Mohammad Ayasrah \\ Taibah University \\ College of Education \\ Department of Educational Technology \\ Medina, Saudi Arabia \\ fayasrah@taibahu.edu.sa/firasayasrah@yahoo.com
}

\begin{abstract}
E-learning has become progressively eminent in higher education, and universities have increased provisions and many students are registering. This paper scrutinizes the factors which predict students' intention to use technology at the Taibah University. To understand the kind of these factors might help Saudi Arabia universities to promote the usage of information and communication technology in teaching and to learn. This research scrutinised the mediating effect of e-learning readiness on the association between factors affecting intention to use university technology namely, trust, hedonic motivation and students' expectation at Taibah University. The study provided details of the findings in every theme highlighted and described the relationships between the factors, using one single model. This study also conducted a comprehensive review of the literature and presented quantitative findings on the intention to use from Saudi Arabia. Based on the findings, there is a positive and significant relationship between trust, hedonic motivation, students' expectation and intention to use, with the mediating role of e-learning readiness. This paper offers a synthesis of the proof e-learning willingness in higher education which add to effective e-learning implementation.
\end{abstract}

Keywords: Intention to Use, Trust, Hedonic Motivation, E-Learning Readiness, Students' Expectation

\section{Introduction}

The Saudi Arabia Education Systems had gone through an unbelievable development with solely one goal in ensuring that educations become more effective, in meeting the religion, financial and social desires of the nation as well as to eliminate illiterates amongst Saudi grownups. SA is the world topmost nation that spend on educations, as per the 2014 national budget, educations and healthcare are still the priorities of the budget. Education received a vast proportions of the budget at $25 \%$ of the entire expenditure, regarded to be the greatest amongst the world (Unnisa, 2014).

The evolutions of e-learning and m-learning technology as well as improvement of distance learning and informal learning methods and the succeeding adaptation of these technologies by higher educational institution, encourage, motivate, and stimulate study environment (Smith \& Barrett, 2014). The government of Saudi Arabia is focusing not merely to enhance traditional teaching approaches but advance flexibilities of learning, promoting an improved learning environment, advance cognitions, improve the learning experiences, assist students to be more collaborative as well as enthusiastically participating in the class via the acceptance of new learning technology (Al-Fahad, 2009). The usage of SMART technology is obtaining acceptance in Saudi Arabian higher educational institution. Saudi scholars have interest in the idea of mixed learning and the way the implementations of m-learning technology could be utilized in supporting or replacing some factors of the traditional learning atmosphere. Though higher education m-learning projects are currently not mature and more empirical than those in school, students in higher educations have facility in connecting their laptop computers and smart phones to the internet wirelessly (Kukulska-Hulme, Sharples, Milrad, Arnedillo-Sánchez, \& Vavoula, 2009).

Alenezi and Karim (2010), claimed that the universities are keen in investing in higher technologies tool and programs which could be valued by teachers and students. Flexibilities as well as enhancement of skills are the two major fields which universities considered while applying technology (Alenezi \& Karim, 2010). Several universities are using technologies to assist every day teachings, for instance, video conference is employed in 
facilitating men professors and lecturers that teach in women universities according to sex segregation policy. The government offers students with technology resources like laptops, tablets and the internet so as to encourage them in pursuing educations (Alenezi \& Karim, 2010).

The general goal of this research is to examine how e-learning can be accepted at Taibah University in facilitating students to e-learn at their conveniences, anytime and anywhere, via their personal technology As portion of this research, it is appreciated to examine Saudi students intentions to utilize technology, e-learning readiness, trust, hedonic motivation, and students' expectation.

\section{The Relationship between Trust and Intention to Use}

Intention to use the technologies is one of the main factors which formed TAM, which consider as the best single predictor of the actual usage (Davis, 1986; Mutahar, Daud, Ramayah, Putit, \& Isaac, 2018). It defined as "a measure of the strength of one's intention to perform a specific behaviour" (Ajzen \& Fishbein, 1975).

Trust still had been getting prime considerations in study because of the ambiguous environments and involvements of exchange of private and delicate information to the service provider (Belanche, Casaló, \& Flavián, 2012; Belanche, Casaló, Flavián, \& Schepers, 2014; Bélanger \& Carter, 2008; Venkatesh, Thong, Chan, Hu, \& Brown, 2011). Therefore, according to the significance of this variable for the successes of this sector, prior scholars in extension researches began to examine the association among trust and intention and they find significantly positive association among this two variables in numerous technology contexts (Belanche et al., 2014; Chong, 2013; Hernández-Ortega, 2011; Hoehle, Huff, \& Goode, 2012; Teo, Srivastava, \& Jiang, 2008). Nevertheless, in spite of the above significant positive association, the findings of (Kassim \& Asiah Abdullah, 2010; Venkatesh et al., 2011) revealed insignificant association among trust and usage intention.

\section{The Relationship between Hedonic Motivation and Intention to Use}

Brown and Venkatesh (2005), define hedonic motivation (HM) as an enjoyment or contentment resulting from utilizing a technology and playing important part to determine new technology acceptance Hedonic motivation would have a significant impact on behavioural intention to utilize learning management system.

Venkatesh, Thong, and Xu (2012), hedonic motivation, illustrate positive impact on behavioural intention usage of learning management system but habit illustrate insignificant. This might be the motive why the students utilize the learning management system for academic purpose only.

Motivation as the interaction for content in the research describes the pleasure of entertainment or hedonic of the users to what having. To get fun or entertained might be the indicator of it. Therefore, hedonic motivation has a direct influence on behavioural intentions as a study conducted in Venkatesh et al. (2012). Furthermore, motivation brings the hedonistic for having pleasure to use the technology be the important factor to determine the user's acceptance and use the technology (Brown \& Venkatesh, 2005). Many previous studies conducted hedonic motivation effect technology acceptance directly and be an important factor (Khatimah, Susanto, \& Abdullah, 2019). There is few studies discuss hedonic as factors affected through users' acceptance (Pillai \& Mukherjee, 2011). There are significant factors in the behavioural intention to use and hedonic information systems and not related to the behavioural intention to use utilitarian information systems (Van der Heijden, 2004).

Therefore, hedonic motivation is important to be a predictor for users' intention towards technology acceptance (Sharif \& Raza, 2017). It indicates that hedonic motivations have an important affect to the behavioural intention.

\section{The Relationship between Students' Expectation and Intention to Use}

Sheppard, Hartwick, and Warshaw (1988), drew attentions to a dissimilarity among behavioural intention and behavioural expectation. While intention denotes what someone intend or plan to do, behavioural expectation denotes self-prediction regarding what someone is probably to do. Measure of behavioural expectations are believed to include persons insights of factor that might obstruct performance of a behaviour, like situational constraints or lack of ability, and might consequently offer good predictors of behaviour than traditional measure of intentions (Warshaw \& Davis, 1985). Supports for this perception come from Sheppard et al. (1988) meta-analysis of the 
theory of reasoned action. Their findings revealed that behavioural expectations were very robustly associated with behaviour than behavioural intentions.

Enthusiasts of the use of technology in educational context, claiming that traditional school should change in order to meet students' expectations, open the way for significant and contextualised learning, decentralising the teacher from the teaching-learning process, by including other sources of information provided by technological devices. According to Conole, De Laat, Dillon, and Darby (2008), the environment surrounding students can be a rich learning environment in which they can select and adjust the available technologies to their own personal needs

A research had been conducted to examine the structural associations amongst students' expectation, perceived enjoyment, perceived usefulness, satisfaction, as well as continuance intention to utilize digital textbook in middle school, according to Bhattacherjee (2001) expectation confirmation model. The respondents of this research were Korean middle school students studying an English class taught by a digital textbook in E middle school, Seoul. Data was gathered through a paper-and-pencil based questionnaire with 17 items; 137 questionnaires were analysed. The finding of the research revealed that expectations have a direct and positive impact on continuance intention to utilize digital textbooks. According to these results, the implications and recommendations for future research were offered (Joo, Park, \& Shin, 2017).

\section{The Relationship between Trust and E-Learning Readiness}

E-Learning could be delineated as the transformations of teaching learning procedures via learner entered methods with the supports of information and communication technologies (ICT) (Aoki, 2010). In line with this meaning, e-readiness is delineated as the measures of the level where communities might be willing as well as ready in making benefits of utilizing ICT (Dada, 2006).

There are two kinds of trust necessary in e-learning implementations. The first one is inner trust, develop in the e-learning projects teams. The second one is inter-trust, among the e-learning projects teams and other stakeholder, like central IS departments or associates outside universities. Distrust could extremely hinder the advancement of every e-learning implementations. Generally, it is comparatively easier to develop the inner trust in an e-learning projects, and typically it is relatively hard to develop the inter-trust with the university central IS departments or among associates from diverse institutions (C.-C. Lin, Ma, \& Lin, 2011).

Based on the scholars, these factors revealed the readiness condition of people for e-learnings (Demir, 2015; Yurdugül \& Sarikaya, 2013). As for Moftakhari (2013) so far the e-learnings readiness degrees of the students is inadequate, the chances to prosper in e-learning is lower. Guglielmino and Guglielmino (2003), indicated that to push people, that are not prepared for e-learnings, to study online would not solely make them in experiencing a negative e-learnings experiences but likewise it would make them to have prejudice for e-learnings activity in the future. Likewise, Piskurich (2004) stated that there are numerous motives behind individual failures in e-learnings environment and usually the motive of the failures is that the students are not prepared for e-learnings.

\section{The Relationship between Hedonic Motivation and E-Learning Readiness}

E-learning readiness is "mental or physical preparedness of an organization for some e-learning experience or action" (Borotis, Zaharias, \& Poulymenakou, 2008). These views specify that an individual or group mental and physical readiness on experiences or activities in this situation is learning online

E-learning is impacted by performances expectancy, social influence, hedonic motivation, and habit. Remarkably, though innovativeness is not significant to utilize intentions, it had a positive influence on E-learning utilization which is comparatively new in Jordan. Specifically, the determinant of performance expectancy, social influence, hedonic motivation, and habit are positively associated to intentions of using E-learning which had in turn a positive influence on the usage of E-learning (Nguyen, Nguyen, Pham, \& Misra, 2014).

\section{The Relationship between Students' Expectation and E-Learning Readiness}

The numbers of online programs that educational institutions are offering are incessantly augmenting at various degrees, that is associate, undergraduate and even graduate degree. Majority of the programs addressed 
grownup students that had a desire for higher education degree, however they do not have the opportunity of accessing traditional educations. Either they just desire or are indebted to enrol in online educations, these grownup students have to be prepared and must to have certain elementary technical skill so as to gain from online learning. They likewise have diverse expectation from the online learning environments. Therefore, evaluating to which degree they are prepared for e-learning and revelation of their expectation of e-learning is vital to the designs and deliveries procedures of e-learning. Furthermore, learners satisfactions level are vital for educators, instruction designers and other shareholders, so as to adapt and review the academics and administrative aspect of e-learning programs in order to upsurge the qualities of the learning environments. Thus, in studying the successes of eLearning, it is vital to disclose not merely the readiness and expectation of students, but likewise the degree of satisfactions regarding diverse dimensions of the learning procedure (Gülbahar, 2012).

Hao (2016), revealed that there are significant associations among secondary school students motivation and expectations; learner control and self-directed learning, technology self-efficacy study, also he revealed that there are a positive association among technology self-efficacy and communication self-efficacy with motivation and expectations. Though there are so many researches relating to factors that affect output of e-Learning, little researches are in existence in the literature regarding the influence of e-readiness and likely factor that influence the output of e-Learning (Keramati, Afshari-Mofrad, \& Kamrani, 2011).

In a study conducted through the researchers Ilgaz and Gülbahar (2015) the aim of this research had been to examine the respondents readiness and expectation before, and the satisfactions level after, an online learning experiences. In line with this aim, at the start of the e-Learning procedure, people must have acknowledged to what level it attain their need and likewise, they must have specified what property it had. Regarding this, it was revealed that their expectation is more objective and these situations provide partakers with opportunities to take better benefit of the systems. It is important to diminish factor which negatively impact satisfactions by assessing them so as to stress on the systems success that originate in negative situation in distant educations. These negative cases drive students away from distant educations, sometime forever. Current researches on the relationship among divers variables previous to, or at the ending of e-Learning, had revealed that persons' academic successes scores, and the satisfactions level, could be analysed and the complete qualities of e-Learning assessed.

\section{The Relationship between E-Learning Readiness and Intention to Use}

Previous research had revealed in their findings that a combination of positive and negative belief regarding technology underlies the field of technology readiness (Dabholkar, 1994; Parasuraman \& Colby, 2007). Particularly, Dabholkar (1994) found that people concurrently harbour positive (favourable) and negative (unfavourable) belief regarding technology. The positive belief push people towards new technology, whereas negative belief might hold them back. Both Dabholkar (1994) and Mick and Fournier (1998) declared that information technology/information system (IT/IS)' customers with more positive belief are more interested and prepared to utilize the diverse new technologies.

Student views of the effectiveness of online tutorials for them could predict stronger enough to which level students intention to utilize online tutorials. Student views of ease to use online tutorials are relatively weak in predicting students intention utilizing the technology. The extent of students readiness in the usage of Online Tutorials illustrates that student motivations and the expectations of successes in utilizing online tools were the utmost strong indicators (Rahardjo, 2018).

The social environment, perceived usefulness and perceived ease of use will have positive effect on the intentions of using e-learning and some of the result suggested that the teachers inclined to had intentions to use the e-learning if they perceive usefulness, ease of use, and social environment supports (Priyanto, Sofyan, \& Surjono, 2017). Consequently, a person's technology readiness could be employed as the basis to understand their intentions to adopt or delaying adopting new technologies (J.-S. Lin \& Chang, 2011).

Bessadok and Abdulsalam (2016), readiness study in Saudi Arabia revealed a scale of readiness for students who struggled with e-learning. This progression of students contains those who have no intention of using elearning without explicit requirements, those who need convincing that e-learning is beneficial, those who are convinced of e-learning but have computer anxiety, and those who faced substantial obstacles and need help overcoming them. 


\section{E-learning Readiness as Mediating}

Numerous scholars had informed on the benefit and advantage of e-learning in Saudi Arabia (Al-Asmari \& Khan, 2014; AlMegren \& Yassin, 2013; Altameem, 2013). Nevertheless, there are a little outstanding concern since the ventures into e-learning in Saudi Arabia strengthens. Students may struggle to adapt to these initiatives since currently they should be leading their own learning procedure (Darling-Hammond, Flook, Cook-Harvey, Barron, \& Osher, 2019). Other students may find it hard in adjusting to the online courses structures (Tayebinik \& Puteh, 2012).

In a research by MacKeogh (2003), only $12 \%$ of students chose e-learning, whereas $20 \%$ of the students prefer the traditional system of learning. The findings specify that, although students were advocates of technologies, numerous of them were not willing to relinquish the face to face learning experiences. In an additional research, Howard (2009) revealed that students in e-learning module miss the face to face interactions with their lecturers and other course mates. The findings of Starenko, Vignare, and Humbert (2007), revealed that students face a huge challenges working with one another in online environments. In contrast, results by (López-Pérez, Pérez-López, \& Rodríguez-Ariza, 2011) revealed that tertiary students appeared to favour online learning as a supplement to traditional approaches of classrooms teachings.

Students' readiness is other strong element in the implementation of online learning effectively (Mosadegh, Kharazi, \& Bazargan, 2011; Rasouli, Rahbania, \& Attaran, 2016). Readiness could be researched by evaluating students' knowledge (George et al., 2014), technology skills (George et al., 2014; Rasouli et al., 2016), technology availability (Anene, Imam, \& Odumuh, 2014; Rasouli et al., 2016), self-directed learning (Chu \& Tsai, 2009; Kaur, 2014), computer and internet efficacy (Kumar, 2017; Seraji, 2013) (Seraji, 2013; Kumar, 2017), and attitude (ElGayar, Moran, \& Hawkes, 2011; George et al., 2014; Kumar, 2017) in e-learning.

Whereas many things are now recognised regarding online learning, there are currently a deficiency of study and plentiful description on students readiness towards e-learning in Saudi Arabia environments. The combination of e-learning and the face to face learning environment might lead to students' disconnection in the elearning in Saudi Arabia models of instructions. Al-Furaydi (2013), proposed that higher education institution had to evaluate their students readiness for e-learning for them to effectively accept the e-learning in Saudi Arabia environments. Almutairy, Davies, and Dimitriadi (2014), also restated this significance by stressing on the perceptions of students as the utmost essential component. By studying the literature, students' readiness for elearning in Saudi Arabia could be categorized into 6 major factors: a) technology skills; b) technology usage; c) technology availability; d) self-directed learning; e) computer and internet efficacy, and f) students' attitude towards e-learning in Saudi Arabia. Hence, this research intended to examine student's readiness for e-learning in Saudi Arabia, and precisely evaluate any important difference among students gender, age, ethnicity, field of study, and level of education, and their readiness for e-learning in Saudi Arabia.

\section{Theoretical Framework}

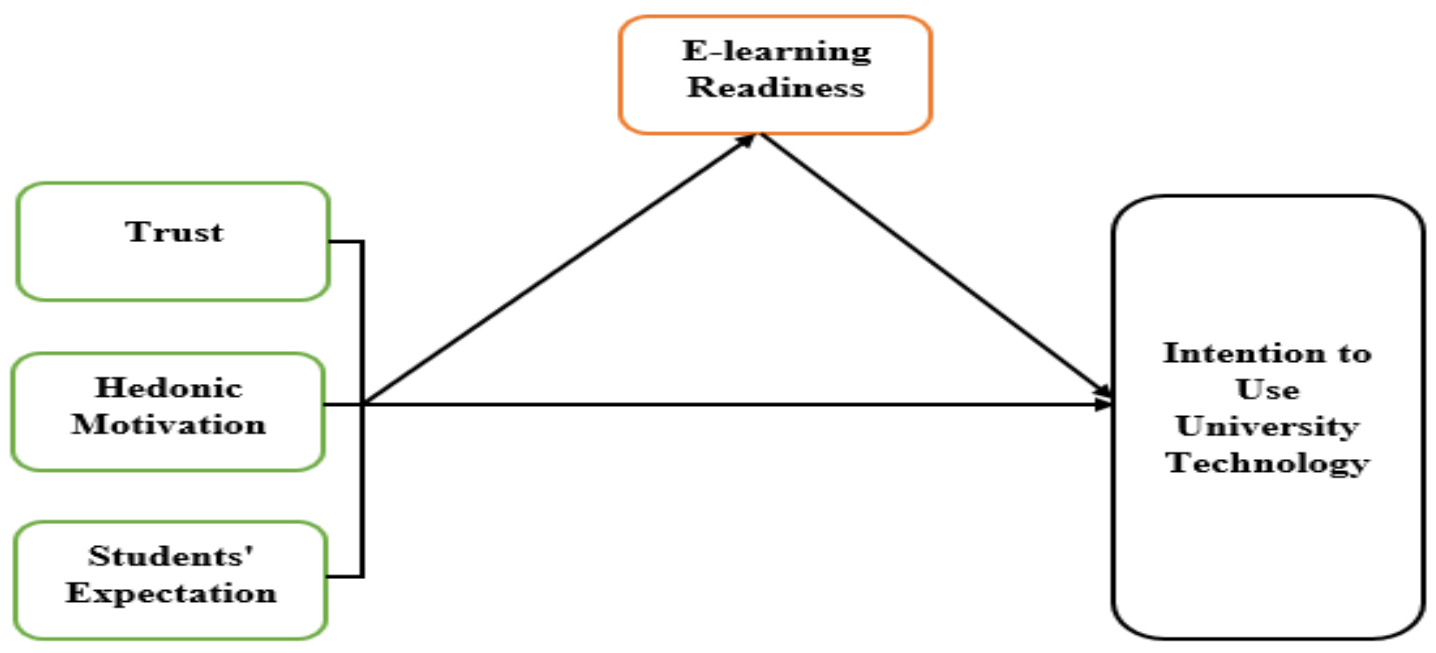

Figure: Research Framework 


\section{Conclusion}

Based on the Saudi Arabian Ministry of Higher Education vision, "the educational tools and modern pedagogy methods are realizing the potential of the education process. In fact, they have a greater impact and a significant effect on education. We are fully aware that neither e-learning nor distance learning should be simple educational goals. Thus, we have made our main goal is to have the most accurate design using the best tools and pedagogy to achieve the social and community needs in the higher education sector in the Kingdom of Saudi Arabia". The students' responses to the new technologies augmented their confidences in their capabilities. Partly, this is the spontaneous responsive attitudes which a huge number of them accept towards every activities where technologies play a role. E-readiness is a measure of the qualities of a nation's information, communications and technological infrastructure and the capability of its customers, business, and governments to utilize ICT to their benefits. Amongst all these institutions, educational institutes played the most important roles. This paper depicts the findings of the e-readiness assessment for students of Taibah University, which is the preliminary phase of a continuing study project. The next phase of the project comprises proper training for the potential e-learners and the design of evaluation based methods for e-learning. Future studies are recommended to test the research model empirically in the same context to assist in confirming the results and in supporting the student characteristics included in the model.

\section{REFERENCES}

Ajzen, \& Fishbein, M. (1975). Belief, attitude, intention and behavior: An introduction to theory and research. Al-Asmari, A. M., \& Khan, M. S. R. (2014). E-learning in Saudi Arabia: Past, present and future. Near and Middle Eastern Journal of Research in Education, 2014(1), 2.

Al-Fahad, F. N. (2009). Students' attitudes and perceptions towards the effectiveness of mobile learning in King Saud University, Saudi Arabia. Online Submission, 8(2).

Al-Furaydi, A. A. (2013). Measuring e-learning readiness among EFL teachers in intermediate public schools in Saudi Arabia. English Language Teaching, 6(7), 110-121.

Alenezi, A. R., \& Karim, A. (2010). An empirical investigation into the role of enjoyment, computer anxiety, computer self-efficacy and internet experience in influencing the students' intention to use e-learning: A case study from Saudi Arabian governmental universities. Turkish Online Journal of Educational Technology-TOJET, 9(4), 22-34.

AlMegren, A., \& Yassin, S. Z. (2013). Learning Object Repositories in e-Learning: Challenges for Learners in Saudi Arabia. European Journal of Open, Distance and E-learning, 16(1), 115-130.

Almutairy, S., Davies, T., \& Dimitriadi, Y. (2014). The readiness of applying m-learning among Saudi Arabian students at higher education. Paper presented at the 2014 International conference on interactive mobile communication technologies and learning (IMCL2014).

Altameem, A. (2013). What Drives Successful E-Learning? An Empirical Investigation of the Key Technical Issues in Saudi Arabian Universities. Journal of Theoretical \& Applied Information Technology, 53(1).

Anene, J., Imam, H., \& Odumuh, T. (2014). Problem and prospect of e-learning in Nigerianuniversities. International Journal of Technology and Inclusive Education (IJTIE), 3(2), 320-327.

Aoki, K. (2010). The use of ICT and e-learning in higher education in Japan. World Academy of Science, Engineering and Technology, 66, 868-872.

Belanche, D., Casaló, L., \& Flavián, C. (2012). Integrating trust and personal values into the Technology Acceptance Model: The case of e-government services adoption. Cuadernos de Economía y Dirección de la Empresa, 15(4), 192-204.

Belanche, D., Casaló, L., Flavián, C., \& Schepers, J. (2014). Trust transfer in the continued usage of public eservices. Information \& management, 51(6), 627-640.

Bélanger, F., \& Carter, L. (2008). Trust and risk in e-government adoption. The Journal of Strategic Information Systems, 17(2), 165-176.

Bessadok, A., \& Abdulsalam, A. (2016). Mining Student's Belief based on E-learning System Readiness. INTERNATIONAL JOURNAL OF EDUCATION AND INFORMATION TECHNOLOGIES, 10, 6-13.

Bhattacherjee, A. (2001). An empirical analysis of the antecedents of electronic commerce service continuance. Decision Support Systems, 32(2), 201-214. 
Borotis, S., Zaharias, P., \& Poulymenakou, A. (2008). Critical success factors for e-learning adoption Handbook of Research on Instructional Systems and Technology (pp. 498-513): IGI Global.

Brown, S. A., \& Venkatesh, V. (2005). Model of adoption of technology in households: A baseline model test and extension incorporating household life cycle. MIS quarterly, 29(3).

Chong. (2013). Understanding mobile commerce continuance intentions: an empirical analysis of Chinese consumers. Journal of Computer Information Systems, 53(4), 22-30.

Chu, R. J. C., \& Tsai, C. C. (2009). Self-directed learning readiness, Internet self-efficacy and preferences towards constructivist Internet-based learning environments among higher-aged adults. Journal of Computer Assisted Learning, 25(5), 489-501.

Conole, G., De Laat, M., Dillon, T., \& Darby, J. (2008). 'Disruptive technologies', 'pedagogical innovation': What's new? Findings from an in-depth study of students' use and perception of technology. Computers \& Education, 50(2), 511-524.

Dabholkar, P. A. (1994). Incorporating choice into an attitudinal framework: analyzing models of mental comparison processes. Journal of consumer research, 21(1), 100-118.

Dada, D. (2006). E-Readiness for Developing Countries: Moving the focus from the environment to the users. The Electronic Journal of Information Systems in Developing Countries, 27(1), 1-14.

Darling-Hammond, L., Flook, L., Cook-Harvey, C., Barron, B., \& Osher, D. (2019). Implications for educational practice of the science of learning and development. Applied Developmental Science, 1-44.

Davis, F. D. (1986). A Technology Acceptance Model for Empirically Testing New End-User Information Systems: Theory and Results.

Demir, O. (2015). The investigation of e-learning readiness of students and faculty members: Hacettepe university, faculty of education example. Unpublished Master Thesis]. Hacettepe University, Ankara.

El-Gayar, O., Moran, M., \& Hawkes, M. (2011). Students' acceptance of tablet PCs and implications for educational institutions. Journal of Educational Technology \& Society, 14(2), 58-70.

George, P. P., Papachristou, N., Belisario, J. M., Wang, W., Wark, P. A., Cotic, Z., . . Car, L. T. (2014). Online eLearning for undergraduates in health professions: a systematic review of the impact on knowledge, skills, attitudes and satisfaction. Journal of global health, 4(1).

Guglielmino, L. M., \& Guglielmino, P. J. (2003). Identifying learners who are ready for e-learning and supporting their success. Preparing learners for e-learning, 18-33.

Gülbahar, Y. (2012). Study of developing scales for assessment of the levels of readiness and satisfaction of participants in e-learning environments. Ankara Üniversitesi Eğitim Bilimleri Fakültesi Dergisi, 45(2), 119138.

Hao, Y. (2016). Exploring undergraduates' perspectives and flipped learning readiness in their flipped classrooms. Computers in Human Behavior, 59, 82-92.

Hernández-Ortega, B. (2011). The role of post-use trust in the acceptance of a technology: Drivers and consequences. Technovation, 31(10-11), 523-538.

Hoehle, H., Huff, S., \& Goode, S. (2012). The role of continuous trust in information systems continuance. Journal of Computer Information Systems, 52(4), 1-9.

Howard, S. B. (2009). The benefits of face-to-face interaction in the online freshman composition course. Journal of Online Learning and Teaching, 5(4), 685-697.

Ilgaz, H., \& Gülbahar, Y. (2015). A snapshot of online learners: e-Readiness, e-Satisfaction and expectations. International Review of Research in Open and Distance Learning, 16(2).

Joo, Y. J., Park, S., \& Shin, E. K. (2017). Students' expectation, satisfaction, and continuance intention to use digital textbooks. Computers in Human Behavior, 69, 83-90.

Kassim, N., \& Asiah Abdullah, N. (2010). The effect of perceived service quality dimensions on customer satisfaction, trust, and loyalty in e-commerce settings: A cross cultural analysis. Asia Pacific Journal of Marketing and Logistics, 22(3), 351-371.

Kaur, N. (2014). Teacher-Led Initiatives in Supporting Learner Empowerment among Malay Tertiary Learners. Malaysian Journal of Learning and Instruction, 11, 101-126.

Keramati, A., Afshari-Mofrad, M., \& Kamrani, A. (2011). The role of readiness factors in E-learning outcomes: An empirical study. Computers \& Education, 57(3), 1919-1929. 
Khatimah, H., Susanto, P., \& Abdullah, N. L. (2019). Hedonic Motivation and Social Influence on Behavioral Intention of E-Money: The Role of Payment Habit as a Mediator. International Journal of Entrepreneurship.

Kukulska-Hulme, A., Sharples, M., Milrad, M., Arnedillo-Sánchez, I., \& Vavoula, G. (2009). Innovation in mobile learning: A European perspective. International Journal of Mobile and Blended Learning (IJMBL), 1(1), 13-35.

Kumar, A. (2017). E-learning and blended learning in orthodontic education. APOS Trends in Orthodontics, 7(4), $188-188$.

Lin, C.-C., Ma, Z., \& Lin, R. C.-P. (2011). Re-examining the Critical Success Factors of e-learning from the EU perspective. International Journal of Management in Education, 5(1), 44-62.

Lin, J.-S., \& Chang, H.-C. (2011). The role of technology readiness in self-service technology acceptance. Managing Service Quality: An International Journal, 21(4), 424-444.

López-Pérez, M. V., Pérez-López, M. C., \& Rodríguez-Ariza, L. (2011). Blended learning in higher education: Students' perceptions and their relation to outcomes. Computers \& Education, 56(3), 818-826.

MacKeogh, K. (2003). Student perceptions of the use of ICTs in European education: Report of a survey.

Mick, D. G., \& Fournier, S. (1998). Paradoxes of technology: Consumer cognizance, emotions, and coping strategies. Journal of consumer research, 25(2), 123-143.

Moftakhari, M. M. (2013). Evaluating e-learning readiness of faculty of letters of Hacettepe.

Mosadegh, H., Kharazi, K., \& Bazargan, A. (2011). Conducting feasibility of e-learning in gas companies in Yazd province. Journal of Science and Technology Information, 3, 547-569.

Mutahar, A., Daud, N., Ramayah, T., Putit, L., \& Isaac, O. (2018). Predicting Perceived Value in Mobile Banking: Are Awareness and Perceived Risk Important. Research Journal of Applied Sciences, 13(2), 112-124.

Nguyen, T. D., Nguyen, T. M., Pham, Q.-T., \& Misra, S. (2014). Acceptance and use of e-learning based on cloud computing: the role of consumer innovativeness. Paper presented at the International Conference on Computational Science and Its Applications.

Parasuraman, A., \& Colby, C. L. (2007). Techno-ready marketing: How and why your customers adopt technology: The Free Press.

Pillai, A., \& Mukherjee, J. (2011). User acceptance of hedonic versus utilitarian social networking web sites. Journal of Indian Business Research, 3(3), 180-191.

Piskurich, G. M. (2004). Preparing learners for e-learning: John Wiley \& Sons.

Priyanto, P., Sofyan, H., \& Surjono, H. D. (2017). The determinats of e-learning usage by teachers of vocational high schools in the Yogyakarta Special Region. Jurnal Pendidikan Vokasi, 7(1), 1-13.

Rahardjo, D. (2018). E-Learning Readiness and Technology Adoption in Online Tutorial.

Rasouli, A., Rahbania, Z., \& Attaran, M. (2016). Students' Readiness for E-Learning Application in Higher Education. Malaysian Online Journal of Educational Technology, 4(3), 51-64.

Seraji, F. (2013). Identification and categorising the skills needed for the virtual student. Journal of Training and Learning Researches, 2, 75-90.

Sharif, A., \& Raza, S. A. (2017). The influence of hedonic motivation, self-efficacy, trust and habit on adoption of internet banking: a case of developing country. International Journal of Electronic Customer Relationship Management, 11(1), 1-22.

Sheppard, B. H., Hartwick, J., \& Warshaw, P. R. (1988). The theory of reasoned action: A meta-analysis of past research with recommendations for modifications and future research. Journal of consumer research, 15(3), 325-343.

Smith, T., \& Barrett, R. (2014). Informal e-learning: the case of small business owners. Education+ Training, $56(2 / 3), 219-232$.

Starenko, M., Vignare, K., \& Humbert, J. (2007). Enhancing student interaction and sustaining faculty instructional innovations through blended learning. Blending Learning: Research Perspectives, 161-178.

Tayebinik, M., \& Puteh, M. (2012). Mobile learning to support teaching English as a second language. Mobile Learning to Support Teaching English as a Second Language. Journal of Education and Practice, 3(7), 5662.

Teo, T., Srivastava, S., \& Jiang, L. (2008). Trust and electronic government success: An empirical study. Journal of management information systems, 25(3), 99-132. 
Unnisa, S. T. (2014). E-Learning in Saudi Arabia's Higher Education. Kuwait Chapter of Arabian Journal of Business and Management Review, 33(2575), 1-6.

Van der Heijden, H. (2004). User acceptance of hedonic information systems. MIS quarterly, 695-704.

Venkatesh, Thong, J., Chan, F., Hu, H., \& Brown, S. (2011). Extending the two-stage information systems continuance model: Incorporating UTAUT predictors and the role of context. Information Systems Journal, 21(6), 527-555.

Venkatesh, Thong, J., \& Xu, X. (2012). Consumer acceptance and use of information technology: extending the unified theory of acceptance and use of technology. MIS quarterly, 157-178.

Warshaw, P. R., \& Davis, F. D. (1985). Disentangling behavioral intention and behavioral expectation. Journal of Experimental Social Psychology, 21(3), 213-228.

Yurdugül, H., \& Sarikaya, D. A. (2013). The scale of online learning readiness: A study of validity and reliability. Egitim ve Bilim, 38(169). 